Winter 2016

\title{
Human Rights and Global Public Goods: The Sound of One Hand Clapping?
}

Neil Walker

Univeristy of Edinburgh, neil.walker@ed.ac.uk

Follow this and additional works at: https://www.repository.law.indiana.edu/ijgls

Part of the Human Rights Law Commons, International Law Commons, and the Public Law and Legal Theory Commons

\section{Recommended Citation}

Walker, Neil (2016) "Human Rights and Global Public Goods: The Sound of One Hand Clapping?," Indiana Journal of Global Legal Studies: Vol. 23 : Iss. 1 , Article 11.

Available at: https://www.repository.law.indiana.edu/ijgls/vol23/iss1/11

This Article is brought to you for free and open access by the Law School Journals at Digital Repository @ Maurer Law. It has been accepted for inclusion in Indiana Journal of Global Legal Studies by an authorized editor of Digital Repository@Maurer Law. For more information, please contactrvaughan@indiana.edu.

\section{$\Psi$}

JEROME HALL LAW LIBRARY

INDIANA UNIVERSITY

Maurer School of Law
Bloomington 


\title{
Human Rights and Global Public Goods: The Sound of One Hand Clapping?
}

\author{
NEIL WALKER ${ }^{*}$
}

\begin{abstract}
Each operating in a presumptively general or universal register, "public goods" and "human rights" are among the most popular and visible contemporary carriers of ideas of global law and governance and are therefore prime sources for any broader project of global justice. Their combination, moreover, holds out the prospect of a fertile engagement between the two core concerns of modern political moralityour collective requirements and potential (public goods) and our individual dignity and well-being (human rights). Yet for all their ambition, public goods and human rights each face the formidable challenge of placing considerations of political authority and political morality in productive balance. Exploring both, we face the frustrating phenomenon of one hand clapping-a failure to reconcile authority and morality in a satisfactory manner. The discourse of global public goods presupposes rather than provides grounds for the relevant "public" and so suffers from a general deficit of political authority. In turn, this reinforces the incompleteness of its claim in political morality. The discourse of human rights, perhaps surprisingly, reveals stronger authoritative roots; however, these are locally situated, and the soil becomes very thin as we move away from the state to the broader global environment and the familiar yet ethically abstracted moral discourse of universal entitlement. In conclusion, I argue, it is precisely because both of these dimensions of global ethics-public goods and human rightsface the same type of difficulty of the grounding political authority that their conjunction in a single scheme does not allow either to compensate for the deficiencies of the other.
\end{abstract}

* Regius Professor of Public Law and the Law of Nature and Nations, University of Edinburgh.

Indiana Journal of Global Legal Studies Vol. 23 \#1 (Winter 2016)

(C) Indiana University Maurer School of Law 


\section{INTRODUCTION}

In a thought-provoking analysis, Daniel Augenstein shines light on an underexamined set of connections between two key terms in our contemporary vocabulary of legal and political philosophy-public goods and human rights - and explores how these connections help us to address questions of planetary justice. ${ }^{1}$ In posing his title question "to whom it may concern," he points us directly to the conflicted nature of the ethics of responsibility for our global well-being. ${ }^{2}$ On the one hand, we hear the familiar open-ended call to all audiences to be "concerned," to take responsibility for what happens beyond the confines of the state and its citizenry. On the other hand, if we put the rhetorical appeal of the phrase to one side, a focus on the question "to whom" highlights the problem of political authorship and so of political authority. Which of us, by what means collectively constituted, has title and voice to assume concern for global politics and public policy? Who is obliged to do so? Who is justified in so doing? On what grounds? With what implications for the content and extent of our common global commitments? And, just as importantly, who has the mobilizing capacity to do so? These questions remain as urgent (surely every one of us shares responsibility for the many contemporary matters of palpable global concern, both immediate and long-term) as their answers appear elusive (but just how do we translate that shared responsibility into a defensible and effective politics of intervention?).

"Public goods" and "human rights" each offer a partial set of answers. But are these answers overlapping or separate, interdependent or independent, complementary or conflicting, complete or incomplete in their combined import? Acknowledging that they deal with distinct aspects of our global legal and political morality-the value of human rights is not (or not only) that they are public goods, nor is the value of public goods exhausted by their contribution to human rights-Augenstein recognizes and examines some of the specific ways in which they are nevertheless interdependent and potentially complementary. But in so doing he leaves open the question of the capacity of these two registers of political thought to provide, in combination, a general answer to the challenge of how to work out and operationalize our global ethics of collective responsibility.

Yet, for a number of reasons, that open question remains an important and intriguing one. First, there is the question of profile to which I alluded. Public goods and human rights are among the most

1. Daniel Augenstein, To Whom It May Concern: International Human Rights Law and Global Public Goods, 23 IND. J. GLOBAL LEGAL STUD. 225 (2016).

2. See id. 
popular and visible contemporary carriers of ideas of global law and governance and are therefore prime candidates for any broader project of global justice. ${ }^{3}$ Secondly, each operates in a presumptively general or universal register. Public goods should in principle be available to any and all publics, while human rights purport to speak in the name of all humanity. In both cases, therefore, the difficulty of freeing the relevant conceptual apparatus from a state-centered frame of reference need not be insurmountable. Thirdly, the two themes may appear to complement each other in their coverage of the substantive domain of global ethics. Whereas public goods focus on matters of collective provision, human rights continue to place the individual at their ethical center. Their combination, therefore, may hold out the prospect of a fertile engagement between the two core concerns of modern political morality-our social obligations, requirements, and potential on the one hand, and our individual dignity and well-being on the other.

In this short paper, I address this question of the larger potential of global public goods and human rights. In so doing, I take up a number of the cues provided by Augenstein and also pursue some lines of my own. My conclusion, however, is a skeptical one. For all their ambition, both public goods and human rights face the formidable challenge of placing considerations of political authority, on the one hand, and political morality, on the other, in productive balance. In the exploration of both themes, we are faced with the frustrating phenomenon of one hand clapping-with a failure to reconcile authority and morality in a satisfactory manner. On the one side, the discourse of global public goods tends to suffer from a general deficit of political authority, which in turn reinforces the incompleteness of its claim at the level of political morality. On the other side, the discourse of human rights, perhaps surprisingly, has stronger authoritative roots. However, these roots are locally situated, and the soil becomes very thin as we move from the state to the broader global environment and to the familiar, yet ethically abstracted, moral discourse of universal entitlement. And in turn, I argue, it is precisely because both of these dimensions of global ethicspublic goods and human rights-face the same type of difficulty that their conjunction in a single scheme does not allow either to compensate for the deficiencies of the other.

3. See generally NEIL WALKER, INTIMATIONS OF GLOBAL LAW 55-130 (2015), for discussion of the rise of public goods and human rights to prominence as candidate species of global law. 


\section{Public Goods and Global Justice}

Augenstein's critique of the application of the standard economistic conception of public goods to a transnational setting follows a well-worn track and ends up facing some familiar puzzles. The attraction of a notion of public goods no longer confined within national boundariesfrom trade and environmental protection to climate change and security-is not fundamentally different from its attraction at a national level. Public goods provide presumptively politically uncontentious and morally unobjectionable reasons for common action on common problems, whether these sound at the national level, global level, or any level in between.

Nonexcludability of access and nonrivalness in consumption are the two defining features of the standard model of public goods. ${ }^{4}$ These two features account for the key characteristics-high production costs, freerider problems, and nonexhaustible benefits - that militate against their adequate, efficient, or equitable provision by private market actors. ${ }^{5}$ Basically, private actors tend to lack either the means or the motivation to supply such goods, and to the extent that they are able and willing to supply, they are inclined to do so in an unnecessarily restrictive manner. This explains why such goods ought to instead be supplied and enjoyed as public goods.

Yet, these defining features are matters of degree. Most public goods, whether on a national or a global scale, are not "pure" public goods. Instead, access to them may be restricted in some measure due to human intervention and technical manipulation. They may also be susceptible to depletion through consumption. In addition, to the extent that public goods retain the attributes of nonexcludability and nonrivalness and so may be more effectively provided publicly rather than privately, this does not place such provision beyond criticism nor beyond the realm of political contention. Such public provision may still vary significantly in intensity and quality. The benefits it bestows will be received and experienced unevenly between different groups, while the balance and trade-off between different public goods involves independent value choices over which disagreement remains inevitable.

These objections apply regardless of the type of public goods with which we are concerned. On the one hand, there are purely instrumental public goods, such as clean air, street lighting, or the provision of other general utilities, where the emphasis is on the public means of delivery. On the other hand, there are communal public goods, where the public

4. See Paul A. Samuelson, The Pure Theory of Public Expenditure, 36 REv. ECON. \& STAT. 387, 387 (1954).

5. See id. at $387-89$. 
good in question makes reference not only to the collective modality and instrument of provision but also to the collective context of its enjoyment. Such communal goods are public goods because the good in question is accomplished and appreciated in (relatively nonexcludable and nonrival) common across a particular community. I am referring to goods such as living in a tolerant society, living in an educated society, or even-to take the case where our two categories do directly intersect-living in a society that respects human rights. We are also referring to a further subcategory of "essentially communal goods" such as a common language, fraternity, or solidarity, ${ }^{6}$ where the good in question does not merely refer to a benefit that will be communally generated and widely shared within a given community but a benefit that is realized as an experience in common; that is to say, the very enjoyment of the good requires and therefore implies its simultaneous enjoyment by others. ${ }^{7}$

If we turn our attention specifically to public goods on a global scale, whether instrumental or communal, we can identify a double political deficit-the two elements of which are closely related. First, as I have already touched on, there remains a deficit of political morality that is already well known at the national level. To identify something as a public good tells us only that we should make public provision for it, not precisely what that provision should be. There will inevitably be winners and losers and disputed priorities in the elaboration of each good. The precision of instrumental public goods suffers from inevitable disputation over what counts as an adequate means and level of provision, while the precision of communal public goods suffers from the abstractness of their specification. The relationship between the various goods is also highly contestable. As Augenstein points out, specification of the overall "public good" to which various goods should contribute and which should inform the terms and balance of their realization also remains absent within the specialist and mutually compartmentalized discourses of public goods. ${ }^{8}$

Secondly, there is a deficit of political authority. Here, the global level acquires its own peculiar vulnerabilities. To name something as a public good does not tell us how we should make provision for it. We call something a public good because the mismatch between our interest in its benefit and our individual and joint motivation to provide it speaks

6. See Jeremy Waldron, Can Communal Goods be Human Rights? in LIBERAL RIGHTS: ColleCted PAPERs 1981-1991 354-59 (Douglas MacLean ed., 1993).

7. See generally, for example, IAN LOADER \& NEIL WALKER, CiviLIZING SECURITY 7393 (2007); JOSEPH RAZ, THE MORALITY OF FREEDOM 255-62 (1986); Waldron, supra note 6, for discussion of distinction between instrumental and communal public goods.

8. See Augenstein, supra note 1 , at 231. 
to a collective-action problem. But it begs the question to say that this requires an equivalent at the global level to the state as public institution and public-good provider at the national level. We simply do not have such institutions in place, or at least have them only unevenly and often embryonically or of fragile standing (think of global public health or climate change regimes, for example, not to speak of global educational regimes). This, in turn, reflects back on two interlinked problems of political morality. One problem concerns the aforementioned indeterminacy and attendant controversy over the justifiable substantive terms of the provision of global public goods. The problem of precision becomes amplified at the global level precisely because we often lack institutions that have the legitimate authority to make difficult choices over the level and quality of provision. A second, underlying problem concerns the satisfaction of the threshold case for public provision at the level of the global or transnational community to complement the largely accepted need for its provision at the nationstate level. This is particularly so at the level of communal public goods. To accept the need for instrumental public goods at the global level in areas such as climate change and disease control requires only an informed and enlightened self-interest-a sense that our own community well-being depends upon the well-being of other communities being similarly secure-and a level of mutual trust sufficient to ground the credibility of common commitments made on the basis of such enlightened self-interest. Even here, the difficulties of making common institutional cause remain profound. Yet, to accept the need at the global level for communal public goods such as the common benefits of living in mutually tolerant communities, educated communities, or communities in which we value the varied riches of our artistic or wider cultural inheritance, the global level requires something more-a prior recognition that, for some purposes of our community membership and participation, the globe itself (or some significant part of it) counts as the relevant unit of society at which the unit-wide distribution and shared enjoyment of a good presumptively matters to all sharers.

So we should not be surprised that we struggle to find the political means to provide any, still less a sufficient, authoritative mechanism of public-goods provision at the global level. To think otherwise-to assume that the broad need for something that requires collective provision, even if that broad need comes to be broadly acknowledged, will lead to agreement over its collective provision-is to commit a functionalist fallacy or at least to live in excessive functionalist hope.

We can better understand both the attractions and the limitations of the public-goods approach if we locate it within a broader framework of 
philosophical thought about global justice. ${ }^{9}$ Crudely, we can understand the requirements of global justice in terms of three different models of global connectedness. We can order these progressively from thinner to thicker expectations of joint action and conceptions of underlying connectedness: first, there is a model of concurrent interests; second, there is a model of mutual responsibility; and third, there is a model of common concern.

The concurrent-interests model concentrates on those areas where, regardless of cultural and ethical differences, we are manifestly interdependent in certain key domains of social life. In these domains, the globe has become a community of palpably common risk and interwoven life chances. The emphasis is on clear and often urgent areas of shared and interactive predicaments and prospects between states and peoples, where both the common harm or benefit and the fact that we have been and remain in a position to act to cause or prevent such harm or secure such benefit to one another, is undeniable and unavoidable. ${ }^{10}$

The mutual-responsibility model reaches beyond the manifest interdependence of the concurrent-interests model to find a deeper seam of causation and associated obligation. The guiding premise here, today perhaps most forcefully portrayed and most extensively developed in the work of Thomas Pogge, ${ }^{11}$ is that the very arrangement of the world into sovereign states and their peoples (with the international resource, borrowing, treaty, and arms privileges consecrated by that statesovereigntist arrangement), and the institutional configuration of statecentered international law and politics that reflects this, is no neutral framework or international "state of nature." Rather, it is a background structure with significant and uneven effects on the global distribution of benefits and burdens. In particular, the historical embedding and perpetuation of these arrangements in ways that systematically favor some parts of the globe over others, specifically those that have been prominent in the original design and continuing refinement of the system, accounts for many of the world's deep inequalities, including the catastrophe of global poverty. It follows from this deeper investigation of the causal dynamics of the world order that those states and their citizens who are responsible for inequalities and other distributive injustices are under a duty to correct or mitigate the harm that they

9. See generally KIMBERLY HuTCHINGS, GLOBAL ETHICS: AN INTRODUCTION (2010) (explaining how to frame the discussion of ethical problems in a global context).

10. This remains the most common framework for thinking about questions of global justice both within the political classes and in the academy. See, e.g., id. at 1-27.

11. See Thomas Pogge, World Poverty AND Human Rights 184 ( $2 \mathrm{~d}$ ed. 2008) (detailing the way the formation of states continues the cycle of poverty). 
have caused, which requires a level of compensatory common action much greater than under the concurrent-interests model.

Finally, the common-concern model argues for a deeper framework of mutual commitment and obligation precisely in view of our common humanity. ${ }^{12}$ It is neither the proximity of our actions and action-effects nor the greater or lesser interdependence due to that proximity which leads us to take responsibility for each other, or to recognize concurrent interests and the associated entanglement of predicaments and prospects, but rather it is a deeper affinity and solidarity as members of the same species.

All three models become increasingly salient under conditions of globalization. Our manifest interdependence increases in the face of climate change, pandemic disease, global insecurity, and similar problems. So too does recognition of the deeper dynamics of the interdependence of our life chances, as does also, partly on account of this denser web of interconnections, a cosmopolitan awareness of our common human condition. Yet the solutions and responses suggested are different. The public-goods approach, certainly in its instrumental dimension, clearly belongs to the first model-that of concurrent interests, with its emphasis on manifest interdependence. Even communal public goods, though they speak at least minimally to some prior sense of global community and the common concern that implies, also respond to the concurrent-interests model to the extent that they argue for the provision of goods (for example, human rights protection for all and toleration of other cultures) that need not involve high levels of resource redistribution and that remain directly relevant to the satisfaction of one's own local interests. In general terms, the second and third models, with their thicker sense of common ties, are more likely to generate notions of global economic redistribution, social reform, and enhanced global institutional capacity that go beyond those we associate with public goods.

Of course, the different approaches are not mutually exclusive. It is perfectly possible to subscribe to the concurrent-interests, mutualresponsibility, and common-concern models together. Most who subscribe to the public-goods model would make at least some concession to the other two. For example, this may be through recognition of the moral jeopardy of untrammeled state sovereignty and a concern to mitigate its effects through doctrines of humanitarian intervention and basic rights protection under the mutual-responsibility

12. See, e.g., Peter Singer, ONe World: The Ethics of Globalization 150-95 (2d ed. 2004); PETER UNGER, LIVING High AND LETTING DIE: OUR ILLUSION OF INNOCENCE 8 (1996). 
model $;{ }^{13}$ or through acknowledgement of at least minimum standards of species-wide humanitarian assistance, ${ }^{14}$ or recognition of a minimum sense of global community in respect of communal public goods, under the common-concern model.

Yet, for all that, important differences remain. The stress upon one rather than the other of the three approaches tends to reveal distinct and, in some measure, rival mentalities of global governance. And the mentality of global governance associated with the public goods approach is undoubtedly a presumptively modest one. It involves no deep interrogation of the underlying state system and assumes that much public provision should tend to remain state-based and statejustified. It assumes the global political sphere to be merely supplementary and one that is both truncated in terms of its consideration of common ends and the search for a deliberated international consensus (truncated because its emphasis is largely on areas of close interdependence and already apparent manifest common cause) and fragmented in form (fragmented because it tends to deal with the public goods associated with each of these areas discretely). ${ }^{15}$

This still leaves open the overall vision to which the adoption of the public-goods approach in any particular instance is linked. The modesty of a public-goods approach may reflect an overall modesty of ambition and justification of intervention in matters of global justice on the part of its sponsors. Or its modesty may be more strategic or instrumental, merely a recognition of the need to establish a secure platform of basic goods before moving on to deeper and more contentious matters. In this regard, the sense of prior global community implicit in the public-goods approach, however lightly registered, hints at a more progressive attitude. So too does the easy semantic link, made by Augenstein and others, between the multiplicity of global public goods and the singular global public good-the latter a standard that beckons us to take into

13. See, e.g., Ronald Dworkin, A New Philosophy for International Law, 41 PHIL. \& PUB. AFF. 2 (2013) (explaining the complex relationship between state sovereignty and international law).

14. See, e.g., Thomas Nagel, The Problem of Global Justice, 33 PHIL. \& PUB. AfF. 113, 118 (2005) (stating that, regardless of the method, justice demands that the well-off help those in poverty). See generally, JOHN RAWLS, THE LAW OF PEOPLES (1999) (discussing how the law of peoples developed from liberal ideas of justice).

15. The precise mode of treatment will differ depending on whether we are dealing with single-shot, aggregate, or weakest-link public goods, but in any case, our current transnational institutional infrastructure seems weakly equipped and vulnerable to capture by strong ideological or epistemic interests. See e.g., Gregory Schaffer, International Law and Global Public Goods in a Pluralist World, 23 EUR. J. INT'L. L. 669, 681-82 (2012); Nico Krisch, The Decay of Consent: International Law in an Age of Global Public Goods, 108 AM. J. INT'L. L. 1, 20 (2014). 
account not only concurrent interests but also mutual responsibilities and common concerns.

But whether the approach is intrinsic and limited in final ambition or strategic and unlimited, it is that same modesty of immediate vision and orientation that questions or restricts the value of the public-goods approach. As I have argued, the public-goods approach tries to sidestep the problem of political authority through the apparent self-evidence of its objectives at the level of political morality. But here we encounter the first problem of one hand clapping. Any effective solution at the level of political morality is likely to be undermined by the absence of political authority. The two hands need to meet. If they do not do so on account of a deficit of political authority, the claims of substance at the level of political morality may either overreach and fail to be implemented or be prey to unilateral implementation by a nonglobally representative, yet hegemonic, political power. ${ }^{16}$ More likely in the case of most global public goods, it may underreach in compensation for a lack of political authority. In addition, the lack of political authority is liable to be reinforced by the poverty of transnational public political engagement and mobilization that any such narrow and fragmented agenda of institutional treatment of global public goods is apt to generate.

\section{Rights BetweEn COMmunity AND Humanity}

If the problem of global public goods is that their intended contribution at the level of substantive political morality is not matched at the level of political authority-which in turn weakens what can be resolved at the level of political morality - to what extent, if any, can the discursive and institutional possibilities of international human rights help tackle the problem?

Augenstein makes two interesting moves toward answering this question. First, he uses an expansive notion of human rights as a way of treating the problem of political authority-accounting for why and how it is that certain levels of political community do authoritatively resolve to put and keep things in common. ${ }^{17}$ Second, he argues that there is something dynamic and reflexive in this process; that is, human rights

16. See generally Jürgen Habermas, Does the Constitutionalization of International Law Still Have a Chance?, in THE Drvided West 115 (Ciaran Cronin ed., 2006) (examining the constitutionalization of international law with regards to the political authority, political morality, and political power). Here Habermas's main concern is to critique the role of the United States as an "enlightened hegemon" in the unipolar political world of the opening years of the 21st century.

17. See Augenstein, supra note 1, at 236. 
are not simply the glue of an already settled sense of political community. ${ }^{18}$ Although human rights are that in part, they are also a lubricant that can unsettle existing conceptions of the boundaries of political community. These two moves are captured in Augenstein's idea that human rights are "constitutive" in relation to "the (overall) public good" as this is defined by, and in turn defines, a community.

To begin with, there is the basic question of the constitutive role of human rights in the generation of political community. Augenstein's key insight here is that human rights are integral to the fashioning of political community inasmuch as they contribute "to the legitimation of state power by re-presenting the general interest of the polity that is not reducible to the aggregated economic self-interest of 'isolated' liberal individuals or the provision of functionally differentiated public goods." 19 That is to say, whereas public goods speak to a deracinated notion of what outcomes are good for any community and whereas a certain narrow sense of liberal rights speaks in a universal register and so is likewise deracinated, a broader conception of human rights allows the community to give particular meaning to its polity-to become the co-authors of its own specific version of an overall public good that includes, but is not exhausted by, the aggregation of public goods or the protection of economic freedom. That broader conception is one that refers, in Habermasian terms, to the "co-originality" of private autonomy (through economic and other liberty rights) and public autonomy (through political rights) in the making of political community and also refers to their symbiosis-with political freedom dependent upon the exercise of personal freedom and vice versa. ${ }^{20}$ Certain features of the structure of rights protection help reinforce this idea of a particularizing function, including their polity-pervasive, crosssectoral remit and their typical textual qualification by considerations of "common interest," "public policy," and similar terms. It seems, therefore, both that human rights are part of the basic recipe, universally applicable, for the making of political community and that they supply the distinguishing and particularizing ingredient "baked into" the dish that any particular constituency of "we, the people" might serve up.

I have reservations about just how much work the idea of rights might be required to do within our political ethics from this

18. $I d$. at 239 .

19. Id. at 241 .

20. See, e.g., Jürgen Habermas, Constitutional Democracy: A Paradoxical Union of Contradictory Principles?, 29 POL. THEORY 766, 767 (2001) (elaborating on the philosophy of "co-originality"). 
perspective. ${ }^{21}$ It is not clear to what extent a vernacular conception of rights contributes to a common sense of political morality sufficient to transform our picture of public goods in aggregate into a thickly mediated sense of the public good; and insofar as rights are conducive of political community, much of the weight must be borne, not by the basic category of liberty rights, but by the "public autonomy" process rights of democratic voice and political participation. This point will be pursued in due course, yet, for the moment, let us give Augenstein his due. For he insists on an important point when he indicates how human rights do not simply represent the universal dimension in our political morality, as many assume, but are also a source of its particularizing dimension and of the sense of legitimate authority associated with the collective articulation of that particularizing dimension.

In making that point, however, Augenstein stresses the open-ended and critically reflexive quality of the search for human rights. For him, "a political collective that commits to protecting human rights empowers its members to invoke humanity against the polity." 22 Clearly, the invocation of humanity speaks to the capacity of the citizenry of the polity to take a critical stance and to adapt and revise their understanding of how rights are implicated in their political community. But of more relevance to us, it also opens the door to the consideration of the relationship between the polity in question and wider human rights claims issuing from beyond the polity. For if, as Augenstein suggests, the proper relationship between the particular polity and general humanity is the reflexive inquiry that always lies at the heart of human rights claims, then it is a challenge that can be posed-and a claim that in principle should be capable of being raised-by outsiders affected by the actions of a polity as much as by insiders. As Augenstein says, this is already implicit in the protection of human rights we accord to resident non-citizens as well as to state citizens and, more pertinently, in the shifting and expanding international law jurisprudence on the extra-territorial human rights obligations of states. $^{23}$

I have considerable sympathy for the idea of the field of human rights developing in accordance with an ongoing dialectic of the particular and the universal. In other work, I have tried to show that it is the irreducible element of universality in all human rights

21. See generally Neil Walker, Constitutionalism and the Incompleteness of Democracy: An Iterative Relationship, 39 RECHTSFILOSOFIE \& RECHTSTHEORIE 206 (2010) (Neth.) (explaining that the complex relationship between democracy and modern constitutionalism needs to be understood better for today's global world).

22. Augenstein, supra note 1 , at 239.

23. See id. at 243. 
discourse-the claim to speak on behalf of all humanity and of their claims as equal rights-holders-that has led to a powerful rhetorical inclusiveness and expansiveness of rights-holding communities and a similar open-endedness of subject matter. ${ }^{24}$ On the one hand, the remorseless claim to universality carries obvious dangers, as it can lead to illegitimate generalization from very specific modes of life, interest constellations, and conceptions of human flourishing. Yet, on the other hand, the insistent ambition of universalism invites alternative or additional narratives of rights in the same universal code. Since the post-War formation of the United Nations and its Declaration of Human Rights, there has been a dramatic world-wide expansion of rights charters and their "indivisible" range of subject matter (including second-generation socio-economic rights and third-generation group and collective rights) in national and international charters and their institutional supports. ${ }^{25}$ This expansion has been driven by assumptions of a universalism of personal scope in rights language and of an internal relationship between the idea of rights protection and a notion of human agency and dignity that entitles human agents to become reflexively responsible for the best understanding of what their human rights catalogue includes. ${ }^{26}$ And in this expansion, we can see not just a onesided particularism but a gradual invocation and partial reconciliation of different particular visions of human rights at higher levels of agreement and institutionalization.

But, beyond these rhetorical and legal-textual developments, we must be careful how far the language of rights will take us in effectively complementing a global language of public goods. It is telling that Augenstein continues to focus on states as the basic units of rights production and protection (and, of course, of their violation and encroachment) in a globalizing world. He does stress the extent to which the rights-based responsibilities of states increasingly extend beyond their territories, especially as regards the question of the occupation of foreign territories and the various transnational public goods and "bads," in particular peace and (in)security, which may be associated

24. See generally Neil Walker, Universalism and Particularism in Human Rights: Trade-Off or Productive Tension?, in HUMAN RIGHTS: OLD PROBLEMS, New PossibILITIES (David Kinley et al. eds., 2013) (describing the element of universality in all human rights discourse).

25. Ever since the Vienna Declaration was adopted at the World Conference on Human Rights in Vienna in 1993, the "universal, indivisible, interdependent and interrelated" character of human rights has been routinely stressed in the public discourse of transnational human rights. See World Conference on Human Rights, Vienna Declaration and Programme of Action, If 5, U.N. Doc. A/CONF.157/23 (June 25, 1993).

26. See, e.g., Jeremy Waldron, Is Dignity the Foundation of Human Rights?, in PHILOSOPHICAL FoundaTIONS OF HUMAN RIGHTS 117-125 (Rowan Cruft et al. eds., 2015). 
with such occupation. ${ }^{27}$ Yet, as vigorous as the International Court of Justice and U.N. Treaty bodies, in particular the Committee on Economic, Social and Cultural Rights, have been in promoting extraterritorial application, this remains a secondary field of activity behind the domestic-rights jurisdiction of states.

What is more, the international institutional and normative architecture of rights protection within and around the United Nations, however densely developed, remains an external source of instruction and exhortation to states to modify their actions, rather than a signal of the emergence of regional or global political communities with their own state-independent authoritative foundations. Indeed, in the one place where the rescaling of political community beyond the state has made significant advances, namely the regional case of the European Union, the driving force has not been human rights. Rather, it has been the expanding common political objectives of the supranational entity, with human rights playing a complementary but essentially subsidiary role in reaction to and as a secondary influence on these expanding common objectives. ${ }^{28}$

The nub of the matter is that while human rights can be authoritatively "constitutive" of the political community of the state in the sense that, as Augenstein indicates, they play a key role in the imaginative reconstruction of community as something other than and beyond "a predetermined ethical self-understanding of the national community," 29 they still require that presupposition of national community-and all the sociological ingredients of common life that makes such a presupposition possible-as a point of collective orientation for their work of political imagination. There remains an important respect in which the "constitutive" construction through rights of national political community, and, more pertinently, of any other potential level of political community beyond the state, can only get off the ground if there is an existing cultural affinity-a rudimentary "we feeling" - of which it can supply a reconstruction. ${ }^{30}$

27. See Augenstein, supra note 1, at 234.

28. See, e.g., Armin Von Bogdandy, The European Union as a Human Rights Organization? Human Rights and the Core of the European Union, 37 CoMmON MKT. L. REV. 1307, 1308, 1335, 1338 (2000) (explaining the focus and control of human rights when implemented by institutions).

29. Augenstein, supra note 1, at 239.

30. See, e.g., Hans Lindahl, Constituent Power and Reflexive Identity: Towards an Ontology of Collective Selfhood, in THE PARAdox of Constitutionalism: ConstituenT POWER AND CONSTITUTIONAL FORM 9, 9-20 (Martin Loughlin \& Neil Walker eds., 2008) (explaining the problems of political affinity). 


\section{THE INAUDIBILITY OF GLOBAL JUSTICE}

In the final analysis, we cannot wish for what is not plausibly available to us. As Augenstein seeks to complement and moderate the pursuit of global public goods, presented as a modestly progressive but still institutionally light and culturally detached transnational force of political morality, with a human rights-centered force of political authority, he is surely correct to insist that the authoritative roots-if not the imaginative heights - of human rights discourse remain located within the state rather than at some higher level of political institutionalization. ${ }^{31}$ Yet, despite this mismatch of levels, can human rights supply an effective accompaniment and stimulus in the register of global political authority to the construction of the public good, more broadly conceived, in the register of global political morality?

I doubt, in conclusion, that this is the case. In the final analysis, human rights discourse possesses a dual and interrelated legacy that limits its ambition at the global level. Not only do the authoritative foundations of rights and rights enforcement remain firmly statecentered; in addition, and closely associated with that statecenteredness, the original and "first generational" form of rights has been one of shielding individuals from the excesses of political power and so, more specifically, from the various governmental organs of the state- understood as the monopolistic holder of political power of the modern age. And while the shift toward extraterritorial jurisdiction and toward viewing human rights claims as imposing positive as well as negative obligations on states-as swords as well as shields-is an ongoing affair, ${ }^{32}$ the magnetic center of human rights law is still the domestic state environment and the liberal project of constraining state power over individuals within that statist box. ${ }^{33}$ That structural bias is reinforced by longstanding doctrines of sovereign autonomy and noninterference that continue to serve as a brake upon all attempts to extend the responsibility of states for those of their rights-related

31. See Augenstein, supra note 1 , at 225.

32. See, e.g., Daniel Augenstein \& David Kinley, Beyond the 100 Acre Wood: In Which International Human Rights Law Finds New Ways to Tame Global Corporate Power, IN'T'L J. HUM. RTS. 1, 3-12 (2015) (regarding the developing area of state responsibility for the extra-territorial human rights violations of global business entities registered within the home jurisdiction).

33. See generally ANDREW Vincent, The Politics of HuMAN RIGHTS (2010) (stressing the continuing civilizing effect of national structures and standards in sponsoring international human rights protection today; describing national citizens' rights, which remain predominately negative rights against the state, as "mentors" of international human rights). 
actions and action-consequences that are experienced beyond their borders.

This suggests how far what remains a basically locally cultivated human rights discourse-its easy resonance in the contemporary circuits of international law and policy notwithstanding-is from providing the authoritative ballast for the development of a more expansively justice-sensitive conception of the public good at a global level. More generally, this conclusion, in demonstrating the problems encountered even by such promisingly open-ended candidates as human rights and public goods, reminds us of how difficult it is to adapt any nationally nurtured legal or political discourse to global requirements. ${ }^{34}$ Once again we see (and do not hear) one hand clapping-this time the old hand of state-based political authority. Yet, absent the kind of fertile transnational cultural soil in which distinctively political rights of public autonomy can become embedded anew and actively reemployed, ${ }^{35}$ but which, crucially, such rights cannot independently generate, the prospect of this hand being brought together with the hand of an expansively engaged and developed conception of the global public good in the name of global justice remains dim. ${ }^{36}$ The ensuing silence indicates just how much any such broader conception struggles to be heard within our existing constellation of political authority.

The contribution of the idea of global public goods and of human rights, separately and in combination, to the alleviation of global wrongs, must remain, therefore, a decidedly less ambitious one. Indeed, I believe that Augenstein and I are in basic agreement on this, and that, in fact, is why he devotes his analysis to the intricacies of the modest contribution global public goods and human rights can make to the improvement of international law and politics rather than to the larger canvas of global justice. Yet, that modest contribution is also one that becomes all the more important in light of the very elusiveness of any project carrying a higher global ambition. I hope to have illustrated this

34. See WALKER, supra note 3, at 178-203.

35. See Habermas, supra note 20 , at 767.

36. See POGGE, supra note 11. Pogge seeks to use a rights-based argument to add ballast to his case for a mutual-responsibility-based redistribution of resources to alleviate global poverty. He argues that our domestic position as rights-holders within Western states makes us co-responsible for those structurally advantaged economic policies of Western states and their governments that cause global poverty. Yet, whatever its longterm merits as frame-changing, transformative political philosophy, an argument that deploys a traditionally state-internal, noninterference-based discourse of legal authority to authorize a state-external, interventionist-based program of action remains institutionally implausible today. In other words, in terms of our understanding of the claims that can be effectively made under the existing state-sovereigntist framework of legal and political authority, Pogge's approach lacks traction. 
elusiveness by examining the difficulties confronting our twin themes' own candidature for any such exalted task. 